УДК 811.294'264.1

DOI 10.31494/2412-9208-2021-1-3-46-52

\title{
THE PECULIARITIES OF USE ROLE AND PLOT GAMES FOR THE DEVELOPMENT OF COMMUNICATIVE COMPETENCE SKILLS OF PRIMARY SCHOOL PUPILS
}

\section{ОСОБЛИВОСТІ ВИКОРИСТАННЯ СЮЖЕТНО-РОЛЬОВИХ ІГОР ДЛЯ ПІДВИЩЕННЯ НАВИЧОК КОМУНІКАТИВНОЇ КОМПЕТЕНЦІЇ УЧНІВ ПОЧАТКОВОї ШКОЛИ}

\author{
Oxana GERASYMENKO, \\ the primary school teacher \\ ОКсана ГЕРАСИМЕНКО, \\ вчитель початкових класів \\ an.skoryk91@gmail.com \\ https://orcid.org/0000-0002-9001-4136
Andryivka establishment of secondry education of I-III degrees
of Andryivka local council
$\triangle 21$, Garazhnyy alley,
v. Andriivka, Donetsk region,
84175
Андріївський заклад загальної
середньої освти I-III ступенів
Андріївської сільської ради
$\triangle$ пров. Гаражний, 21,
с. Андріївка, Слов'янський р-н,
Донецька обл., 84175 \\ Original manuscript received: December 03, 2021 \\ Revised manuscript accepted: December 15, 2021
}

\begin{abstract}
Game is a form of organization of student life, in which the teacher can, using various methods, to form oral skills, the features of which are: initiative, contact, spontaneity, emotional coloring. Role-playing games in foreign language lessons should be organized by the teacher in advance, using additional materials, supports and visual aids. The place of role play depends on the degree of readiness of the class for it, taking into account the real capabilities of each student.

Communicative and cognitive activities in the classroom are designed to ensure the integrity of the language learning process through the use of role-playing games and it allows students to fully immerse themselves in a foreign language culture through the roles offered to students within a particular topic. The experience of playing games at school has established that students have experience of playing games, they are active, inquisitive and ready to prepare for the game without the help of a teacher.

The use of role-playing games in foreign language lessons provides an opportunity to increase interest in a foreign language, creates a positive attitude to its study, stimulates independent thinking, and most importantly, role-playing games affect language development and affect the development of speaking, reading, listening and writing skills. at the senior stage of training. Role-playing games promote the activation of communicative and cognitive activities, thus ensuring a continuous process of learning a foreign language through work with dictionaries, additional literature sources, the use of interdisciplinary links.

There are many types of games, including role-playing. Role-playing is an important component of foreign language learning: role-playing performs many of the functions necessary for successful learning. The game situation in the lesson provides immersion in the research topic, removes the language barrier, creates a favorable psychological atmosphere.
\end{abstract}


Role play should be conducted under the strict control of the teacher and planned in advance, ensuring the integrity of the learning process. Role-playing games can not do without props or communication situations. Roles between students should be distributed according to students' abilities and the level of language proficiency. process, role.

Key words: communicative competence, development, game, educational

Introduction. In the conditions of realization of tasks of reform of comprehensive school teachers and methodologists constantly look for reserves of increasing of level of quality and efficiency of training of pupils of primary classes. One of these reserves can be considered a role game, which serves as an effective means of creating a communicative focus of lessons of primary school students. Role game, being the most accurate and accessible model of learning, is the organizational form of learning that allows you to optimally combine group, pair and individual forms in the lesson.

Based on the results of participation in role-playing games with children, the foundations of communicative competence is laid, which allow students to communicate and interact in the lessons of primary school students, which is the main purpose of learning.

The relevance of the problem is caused by many factors. First, the intensification of the educational process aims to find ways to support students' interest in the research material and intensify their activities throughout the lesson. Educational games are an effective way to solve this problem. Secondly, one of the most important problems of teaching primary school students is the teaching of oral speech, which creates conditions for the disclosure of communicative function and allows to bring the learning process closer to the conditions of real communication, which increases motivation to learn. Involvement of students in oral communication can be successfully carried out in the process of play activities.

The purpose of research is to identify the importance of role-playing games and the development of role-playing games for the implementation of communicative and cognitive activities in primary classes.

The object of research is the learning process based on the use of role-playing games in primary school.

The subject of research is the method of using role-playing games in primary school lessons as a means of development communicative and cognitive activities.

The theoretical significance of the study lies in the justification and selection of the most important in theoretical terms of the essence and methodology conducting role play as a means of intensifying communicative and cognitive activities at the stage of learning in primary school.

The practical significance of the study lies in the development and conducting of role-playing games, in highlighting the features of role-playing games at the stage of learning in primary school.

Analysis of research and publications. The theoretical and methodological basis of the study are the works of domestic and foreign scientists in the field of psychology, pedagogy, (N. Bagramova, G. Baev, 
V. Baidenko, M. Bakhtina, I. Bim, L. Vygotsky, N. Galskov, N. Gez, N. Grishanov, P. Gurvich, G. Elizarova, N. Zhinkina, I. Zimniaia, R. Kaplan, Y. Kolker, Y. Komarova, M. Kopylovskaya, N. Koryakovtseva, L. Kuzmina, A. Leontiev, O. Leontiev, I. Lerner, T. Lilly).

Results and discussions. The lesson at primary school is considered as a social phenomenon, where the classroom is a certain social environment in which teachers and students enter into certain social relationships with each other, where the learning process is the interaction of all present. At the same time, success in learning is the result of collective use of all learning opportunities. Students must make a significant contribution to this process. The use of various kinds of games provides ample opportunities for activating the educational process. According to the definition of TV Semenova, play is an activity that gives all its participants the right to free expression (Alekseev, 2005)/

E. Byrne, the greatest Western psychologist and practical psychotherapist, defines the concept of the game through the term transaction - a unit of communication. Such sequences of transactions, based, in contrast to time, on individual planning, he calls games. For E. Bern, the game is a way of structuring time in other means such as ritual, pastime, activity. Each member of a social group seeks to enjoy transactions with other members of the group (Allan, 2006).

The game is a small situation, the construction of which resembles a dramatic work with its plot, conflict and characters. The main element of the game is the role of the game, not so important what; it is important that it helps to recreate the various human relationships that exist in life. Only if we isolate and base the game on the relationship between people, it will be meaningful and useful. As for the developmental significance of the game, it is inherent in its very nature, because the game is always emotions, and where there are emotions, there is activity, there is attention and imagination, there is thinking. Playing in class is a complex carrier of information. In the course of the game, associative, mechanical, visual and other types of memory are triggered at the request of the game situation. Thus, on the one hand, the game permeates the entire course, organically manifesting itself in almost every lesson, on the other-takes up about a fifth, without displacing valuable practical activities. It is possible to study the necessary material of the student or having compelled, or having interested it. The game involves all students to the extent that they are capable. The educational material in the game is assimilated through all the organs of information reception, and this is done effortlessly, of course, while the activities of students are creative, practical. There is a $100 \%$ activation of cognitive activity of students in the classroom. Competitive work, the opportunity to consult, the most acute shortage of time-all these game elements contribute to the intensification of students' learning activities, form an interest in the subject (Alekseev, 2005).

During the game, the situation is played several times and each time in a new version. During the game, students have a sense of equality, enthusiasm 
and ability to perform tasks, which, in turn, creates a favorable psychological atmosphere. The language barrier is easier to overcome in the game, new material is imperceptibly assimilated. But at the same time the situation of the game is a situation of real life. Despite the clear conditions of the game and the limitations of the language material used, it must have an element of surprise. Therefore, the game is characterized by spontaneity of speech. Linguistic communication, which includes not only the language itself, but also gestures, facial expressions, etc., is purposeful and mandatory (Hinkel, 2009).

According to L. Bocharova, the game situation in an English lesson allows you to perform very important methodological tasks:

1) ensuring the natural necessity of repeated repetition of language material by students;

2) training students in choosing the necessary language model, which is a preparation for the situational spontaneity of language;

3 ) creating a favorable psychological climate in the classroom, which allows to prepare children for language communication (Alekseev, 2005).

It is customary to distinguish between two main types of games: games with fixed rules, open rules and games with hidden rules. Examples of games of the first type are most didactic, cognitive and mobile games, this also includes developing intellectual, musical, fun games, attractions.

The second type includes role-playing games. Games differ in educational content, children's cognitive activities, play activities and rules, organization and relationships of children, the role of the teacher. The following types of games can be represented in this classification: games with toys; board printed games; word games; pseudo-plot games (Allan, 2006).

This differentiation of games emphasizes their focus on learning, cognitive activity of children, but does not sufficiently reveal the basics of didactic games-features of children's play activities, game tasks, game actions and rules, organization of children's lives, tutor guidance. There are several types of didactic games, grouped by type of student activity: travel games; assignment games; guessing games; puzzle games; conversation games (dialogue games) (Samoukina, 1996).

The choice of game primarily depends on what kind of child she needs, what educational tasks need to be solved. If the game is a team, you need to know well the composition of the players, their intellectual development, physical fitness, age, interests, levels of communication and compatibility, etc. According to K. Livingstone, the game is always associated with different experiences of students: excitement, a sense of responsibility, the triumph of victory, the joy of success, despair, sadness in case of failure, and others. Introducing elements of curiosity directly related to the study of the material creates positive emotions that ensure the successful conduct of purposeful activities of students. The choice of game depends on the time of its holding, the length of time, the availability of game accessories, the specific situation in the educational team. The game is able to function as a means of obtaining something, although the source of its activity is the tasks voluntarily undertaken by the teacher, game creativity and the spirit of competition. The 
use of games has a positive effect on the development of communicative abilities of students, mastering communication in the unity of all its functions: informational, regulatory, value-oriented and etiquette. Students develop compensatory skills, the ability to overcome the lack of language. Students learn to act in a team, to find approaches to other people. Without playful actions, the consolidation of new vocabulary in a child's memory is less effective and requires excessive mental effort, which is undesirable. The game, introduced into the educational process in primary school classes as one of the teaching methods, should be interesting, simple and lively, contribute to the accumulation of new language material and consolidate previously acquired knowledge (Allan, 2006).

Thus, games allow you to create a favorable emotional background in the classroom, which leads to the removal of the language barrier, promotes the development of learning motivation, increases interest in the subject. The game serves as an important source of formation of the child's social consciousness. One type of game, namely role-playing, is a clear example of the effective use of games, which helps students to master various aspects of communication. Playing as a means guarantees the positive emotional state, increases the efficiency and interest of teachers and students in contrast to the monotonous performance of certain tasks.

For the successful implementation of the communicative tasks of the lesson, many methodologists, such as T. Karikh and P. Lovkova, there are many models of lessons based on communicative and cognitive activities through roleplaying games. Role-playing games have a special meaning for learning as a means of activating communicative-cognitive activity in the lesson (games in the form of dialogue, monologue, monologue in dialogue, dialogue in monologue, polylogue, communication (monologue-message, reasoning, proof, etc.), Conversations, disputes, questions and answers, dialogues, etc.). There are several parameters for creating the optimal model for this type of lesson:

1) the nature of the impact of joint activities on the content, selection and organization of educational language and speech material;

2) modeling in the educational process of communication situations and ways of forming language skills and abilities in students;

3) methods and techniques of management of educational activities in the classroom with the teacher and in independent work (Alekseev, 2005).

The proposed model clearly and fully reflects the methodology of the lesson on the basis of communicative and cognitive activities. There are several stages:

Actualization of knowledge.

On this stage there is an actualization of existing knowledge, methods of action in new conditions; formation of the ability to ask questions; development of voluntary attention and memory, cognitive interests and initiative of students; formation of communicative skills, culture of communication, cooperation. The teacher provides material that allows the transition to the study of new material. It can be a repetition of vocabulary on a particular topic. The teacher should choose a game so that students can easily memorize their lexical minimum. An example of 
such a game can be a meeting at the station, bus, shop; conversation in the hospital, at home, at school (Hinkel, 2009).

Commenting on one's own actions.

Tasks are offered that encourage students to identify and choose the types of work to achieve the objectives of the lesson, the teacher helps to comment on the learning activities of the "leader» (strong student). The teacher creates conditions for cooperation - work in pairs, groups. Students can say aloud the algorithm of actions during the joint performance of typical tasks for the use of lexical material, along the way comment on their own actions and avoid mistakes.

Reflection (lesson summary).

Students evaluate each other's own knowledge, jointly check the work done in class. Students can be asked to name the most successful roles of students, their answers (Hinkel, 2009).

Thus, communicative-cognitive activity promotes the development of individual, personal characteristics. A situation of success and self-expression is created, the participants of communication feel safe from criticism, persecution for mistakes, the educational norm is considered to be certain violations of language rules and accidental mistakes. Role play provides the implementation of communicative and cognitive activities through the interaction of a group of students who actively support the act of play.

Conclusion. One of the most important components of the process of improving communicative competence is communicative-cognitive activity as a means of communication in simulated situations. Communicative and cognitive activities can be implemented through various sources, such as textbooks, audio and video materials, Internet resources. Such activities allow students to navigate freely in the phenomenon under study, and one of the functions is the interest of students in learning to communicate. This activity satisfies the need to speak, there is an accumulation of knowledge. Through role play, communicative-cognitive activity can be manifested as planning their language behavior, full understanding of the phenomenon under study, as well as communication between classmates. This activity allows us to compare the studied phenomena in the dialogue of science, psychology and pedagogy.

\section{Literature}

Алексєєв, Н. Г. Організаційно-діяльнісна гра: можливості в області застосування. Вісник вищої школи. 2005. № 7. С. 30-35/

Ельконін, Д. Б. Психологія гри. Москва : Педагогіка, 1978. 304 с.

Полат, Е. С. Навчання у співпраці. Іноземні мови в школі. 2000. № 8. С. 20-25.

Самоукина, Н. В. Організаційно-навчальні ігри в освіті. Москва : Народна освіта, 1996. 251 с.

Allan M. Teaching with games. London : Longman, 2006. 153 p.

Hinkel E. Culture in Second language Teaching and Learning. Cambridge. Cambridge University Press, 2009. 321 p.

\section{References}

Aleksieiev, N. H. (2005). Orhanizatsiino-diialnisna hra: mozhlyvosti v oblasti zastosuvannia [Organizational and activity game: the abilities of use]. Visnyk vyshchoi shkoly - The edition of higher school, 7, 30-35 [in Ukrainian]. 
Elkonin, D. B. (1978). Psykholohiia hry [The psychology of game] Moscow : Pedahohika [in Russian].

Polat, E. S. (2000). Navchannia u spivpratsi [The teaching in interwork]. Inozemni movy v shkoli - Foreign languages at school, 8, 20-25 [in Ukrainian].

Samoukyna, N. V. (1996). Orhanizatsiino-navchalni ihry $v$ osviti [Organizational and educational games]. Moscow : Narodna osvita [in Russian].

Allan M. (2006). Teaching with games. London : Longman. [in English].

Hinkel E. (2009). Culture in Second language Teaching and Learning. Cambridge. Cambridge University Press [in English].

\section{АНОТАЦІЯ}

Гра є тією формою організації життєдіяльності учня, в умовах якої педагог може, застосовуючи різні методи, формувати навички усного мовлення, особливостями якої є: ініціативність, контактність, спонтанність, емоційна забарвленість. Рольові ігри на уроках іноземної мови повинні організовуватися учителем заздалеаідь, з використанням додаткових матеріалів, опор і наочності. Місце рольової гри залежить від ступеня підготовленості до неї класу, з урахуванням реальних можливостей кожного учня.

Комунікативно-пізнавальна діяльність на уроках покликана забезпечити цілісність процесу навчання мови через використання рольової гри і вона дає можливість учням максимально повно зануритися в іншомовну культуру через ролі, які пропонуються учням у рамках певної теми. Досвід проведення ігор в школі встановив, що в учнів є досвід проведення ігор, вони активні, допитливі і готові до самостійної підготовки до гри без допомоги вчителя.

Використання рольових ігор на уроках іноземної мови дає можливість підвищити інтерес до іноземної мови, створює позитивне ставлення до його вивчення, стимулює самостійну речемислітельной діяльність, а головне, рольові ігри впливають на освоєння мовного матеріалу $і$ впливають на розвиток навичок говоріння, читання, аудіювання та письма учнів на старшому етапі навчання. Рольові ігри сприяють активізації комунікативнопізнавальної діяльності, тим самим забезпечуючи безперервний процес навчання іноземної мови через роботу зі словниками, додатковими літературними джерелами, використанням міжпредметних зв'язків.

Існує безліч видів ігор, в тому числі рольові. Рольова гра є важливим компонентом навчання іноземної мови: рольова гра виконує безліч фуннкцій, необхідних для успішності навчання. Іарова ситуація на уроці забезпечує занурення в досліджувану тему, знімається мовний бар'єр, створюється сприятлива психологічна атмосфера. Рольова гра повинна проводитися під чітким контролем вчителя і плануватися заздалегідь, забезпечуючи цілісність процесу навчання. Рольові ігри не можуть обходитися без реквізиту або ситуації спілкування. Ролі між учнями повинні розподілятися по можливостями учнів і за рівнем знань мови.

Ключові слова: комунікативна компетенція, розвиток, гра, освітній процес, роль. 